\title{
Examining Polytechnic Students' Metacognitive Reading Strategies using Think-Aloud Protocols Technique
}

\author{
Mornita Deri, Sarimah Shamsudin
}

\begin{abstract}
Text comprehension is the essence of reading. It plays a vital role in learning especially in the acquisition, sharing, and construction of knowledge. Many researchers have highlighted that metacognitive strategies are critically important aspects of skilled reading. Metacognition is basically referred to thinking about thinking. In the field of reading, metacognitive reading strategies are those activities that make readers aware of their thinking as they engage in reading tasks. Since reading is a cognitive enterprise, readers must apply metacognitive knowledge and must invoke conscious and deliberate strategies in order to achieve comprehension of text successfully. In this study, we will present the findings of the research which concentrate on metacognitive reading strategies used by students of Politeknik Kuching Sarawak when reading English texts. From the think aloud analysis, it was revealed that comprehension problems are the result of the students' limited strategy repertoires and poor strategy choice and comprehension monitoring. From the results of the study, we concluded that teaching metacognitive reading strategies should be taken into account in developing students' reading comprehension.
\end{abstract}

Index Terms: Metacognitive Reading Strategies; Reading Difficulties; Text Comprehension.

\section{INTRODUCTION}

Reading can be a challenging activity especially when the text is unfamiliar, technical or complex (1). It is because comprehension is the reason for reading. Comprehension refers to the ability to process text, to go beyond words and understand its meaning, and to connect between what readers read and what they already know and to give a deep thought of what they have read (2). Readers' ability to comprehend text is largely influenced by their skills and the ability to process text information, and this acquisition of reading takes years to develop. Having said that, reading is indeed a higher order skill which involves learners to apply appropriate reading strategies to cope with reading task demands such as to understand and remember task demands, identify and select reading, monitor comprehension and learning, and synthesize and evaluate a text critically.

Comprehension is not always effortless and fast especially for the struggling L2 readers as Eskey (3) states "reading

Revised Manuscript Received on 14 September, 2019.

Mornita Deri, Universiti Teknologi Malaysia, 81310 Johor Bahru, Malaysia, mornita.d@gmail.com

Sarimah Shamsudin, Language Academy, Universiti Teknologi Malaysia, 54000 Kuala Lumpur, Malaysia.. may be both a means to the end of acquiring the language, as a major source of comprehensible input and end in itself, as the skill that many serious learners most need to employ". In the context of ESL, readers may be capable of reading and understanding each word separately, but their deeper levels of comprehension can be seriously compromised due to failure to link them together to make meaningful ideas. For students to adequately comprehend text, they must possess an awareness of print and that includes decoding skills and metacognitive strategies so that they can monitor their comprehension and reflect on what is read (4). Metacognitive strategies in reading are particularly important should there be a breakdown at any level of comprehension. Over the years, there has been abundant evidence on reading that emphasizes the role of metacognition as a significant contributor to success in second and foreign language learning. Many researchers have highlighted that metacognitive strategies are critically important aspects of skilled reading. According to McNamara (1) "one source of evidence is that successful readers know when and how to use deliberate strategies to repair comprehension". Metacognition is basically referred to thinking about thinking. In the field of reading, metacognitive reading strategies are those activities that make readers aware of their thinking as they engage in reading tasks (5).

Therefore, the focus of this paper is to provide a detailed description of metacognitive reading strategies used by two students of Politeknik Kuching Sarawak in reading an English text. This description encompassed strategies these readers used while reading English text, reading problems that they encountered and choice of strategies to cope with the problems. Indeed, understanding learners' cognitive processes while reading and what strategies they use is the most important means to help them improve their comprehension and learning from the text.

\section{LITERATURE REVIEW}

Metacognition has been defined in various ways by many researchers over the years (6-12). For instance, Flavell (9) coined the term "metacognition" as "one's knowledge concerning one's own cognitive processes and products or anything related to them". In his later research, Flavell (10) suggests that metacognition is the monitoring of a wide variety of cognitive enterprise which

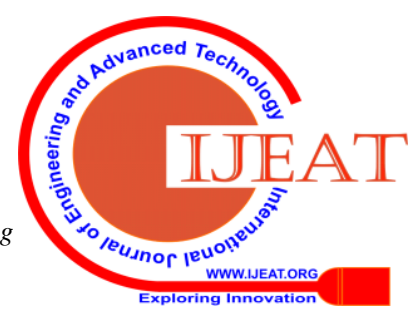


exists through the interactions of metacognitive knowledge, metacognitive experiences, goals (or tasks), and action or strategies. Other researchers such as Brown (8) defines metacognition as knowledge and control of the cognition domain. As for Livingston (13), metacognition is a higher order thinking that comprises learners' active control over their cognitive processes engaged in successful learning.

Metacognition can be divided into three important components namely metacognitive knowledge, metacognitive regulation, and metacognitive experiences. Metacognitive knowledge is what individuals know about themselves and others. Metacognitive knowledge can sometimes be called metacognitive awareness. Metacognitive regulation is referred to metacognitive activities that aid learners to take control of their learning (14). Metacognitive experiences are related to experiences that have to do with cognitive endeavors and these experiences include one's feelings, estimates or judgement related to the features of learning task, the cognitive processing and its outcome (15).

Research on reading comprehension has shown the importance of metacognitive reading strategies in facilitating comprehension. Reading is viewed as an active activity whereby readers are active processors of information who constantly seek out information to remediate problems and use their prior knowledge to achieve learning, through the use of learning strategies. Metacognitive reading strategies have become one of the effective ways to foster students reading comprehension. Readers who are metacognitively aware are called proficient readers because they use more than one metacognitive strategy to aid comprehension. As explained by Anderson (16), "strong metacognitive skills empower language learners: when learners reflect upon their learning, they become better prepared to make conscious decisions about what they can do to improve their learning". In contrast, learners without metacognitive approaches are essentially learning without direction to plan their learning, monitor their progress and evaluate their accomplishment (17).

\section{METHODOLOGY}

The study described here was carried out at Politeknik Kuching Sarawak (PKS), Kuching, Sarawak, where a large number of local students who finished their secondary school came to study.

\section{A. Subject}

There were two participants involved in the present study. Alice and Hanis (not their real names for privacy reasons) had volunteered to participate in a think-aloud protocols at the said institution. They are both of semester 4 students who enrolled in Malaysian English University Test tuition class for March 2018 session. These participants come from two different fields of study - commerce and petrochemical engineering. Table 1 below is a description of participants' profile.
Table 1: Participants' profile

\begin{tabular}{llllll}
\hline Name & $\begin{array}{l}\text { Langu Department } \\
\text { age at } \\
\text { home }\end{array}$ & $\begin{array}{l}\text { Se } \\
\text { me } \\
\text { ster }\end{array}$ & Race & $\begin{array}{l}\text { Age Gend } \\
\text { er }\end{array}$ \\
\hline Alice & $\begin{array}{l}\text { Englis Commerce } \\
\text { h or }\end{array}$ & 4 & Melan & 20 & Femal \\
& $\begin{array}{l}\text { au } \\
\text { Malay }\end{array}$ & & & e \\
Hanis & Malay Petrochemical & 4 & Bajau & 20 & Male \\
\hline
\end{tabular}

\section{B. Instrument}

In order to assess students' metacognitive reading strategies, participants were given one expository English text entitled "The internet can end global inequality. Here's how" by Parekh (18) which consists of 776 words. The text was taken from World Economic Forum (online). The reading level of this text (as measured by Flesch Kincaid Reading Ease) was at 43.8 which should be sufficiently difficult to require strategic behavior by the chosen participants.

\section{Procedure}

The data were collected by the researcher. Each subject participated in a 1.5-hour session and met individually with the researcher. To acquaint the students with think-aloud process, the session began with a short orientation to the technique of thinking aloud. The students were given a sample text for training purpose. The researcher demonstrated the think-aloud task by reading aloud the first paragraph and at the same time, the researcher speaks aloud the thoughts in her head as she engaged in reading. The student then was told that he/she was going to do the same task similar to the demonstration given and he/she was to report to the researcher each of his/her thoughts as they occurred. The student was given a reminder that the objective of the think-aloud activity is to examine their strategies used in reading comprehension. This task took about 30 to 40 minutes depending on how well the students get used to the think-aloud process. This task was not scored because the objective was to familiarize the students with the think-aloud task.

The actual think-aloud was took place immediately after the training. The students were given a text entitled "The internet can end global inequality. Here's how". The students were asked to read aloud each sentence at a time and articulate what he/she was doing or thinking while reading especially the strategies they used to help them understand the passage. All responses and prompts by both the researcher and the students were taped recorded and written verbatim. The think-aloud protocols were analyzed based on reading strategies classification proposed by Mushait (19) (See Table 2). Strategy count is purely based on types of strategies which appeared during think-aloud process. Based on the Table 2 below, RS referred to reading strategies. Mushait has listed 41 reading strategies which 21 strategies are text-related strategies, 16 strategies are word-related strategies, and four metacognitive strategies. 
Table 2: Reading Strategies Classification by Mushait

\begin{tabular}{l} 
Text- related \\
\hline $\begin{array}{c}\text { Top - } \\
\text { down } \\
\text { strategies }\end{array}$ \\
RS1: \\
Paraphrasi \\
ng
\end{tabular}

RS2:

Predicting

/hypothesi

zing about

meaning

(2003)

Word-related
strategies

Botto

Bottom -
up
strategies

Top -

m -

up

S

strat

RS16:

Skimming

RS22: $\quad$ RS26

egies

reading

:

after

Refer

ring

encounte

ring a

to

problem

diffic

(e.g.

ulty

with

unknown

an

word) unkn

with own

intention word

of using

later text

to draw

inference

$\mathrm{s}$ from it

RS17:

adjusting

the size of

the chunk

read at one

RS23:

RS27

Relating

to

knowledg

e of the

:

RS38:

g what

what to

RS39:

ing the

$\mathrm{g}$ the choice
Metaco gnitive

strategi

Keeping

time such

as phrases,

words,

sentences,

and

paragraphs

L1 at the

word

level

Plannin

strategy

to use or

do while

reading.

RS20:

Questionin

g 3

(showing

lack of

comprehen

sion)

general or

subject

specific

Monitor

cessin strategy

lexico

$\mathrm{n}$ to

try to

find $/ \mathrm{r}$

ecall

the

mean

ing of

a

word

he

thoug

ht to

be

know

$\begin{array}{ll}\text { RS3: } & \text { RS18: } \\ \text { Correcting } & \text { Rereading } \\ \text { previous } & \\ \text { error / } & \\ \text { revising } & \\ \text { previous } & \\ \text { misunders } & \\ \text { tanding } & \\ \text { RS4: } & \text { RS19: } \\ \text { Keeping } & \text { Translating } \\ \text { the } & \\ \text { meaning } & \\ \text { in mind } & \end{array}$

RS24: $\quad$ RS28

Relating

to Skipp

knowledg ing

e of the

L2

RS25: $\quad$ RS29

Guessing :

using Using

immediat synon

e context yms
RS40:

Monitor

ing or

evaluati

ng

successf

ul

compre

hension

RS41:

comme

nting on

strategy

used
Relating to

personal

experience

RS6

uxperience

RS7:

Relating to

cultural

knowledge

RS8:

Relating

knowledge

of formal

schemata

(making

use of text

structure)

RS9:

Looking

for the

main ideas

RS21:

RS31

Focusing in

grammar

:

Refer

ring

to

dictio

nary

RS32

Appe

aling

to

resear

cher

RS33

Mark

ing

the

text

RS34

Guess

ing by

using

morp

holog

y /

gram

mar

RS10:

Summariz

RS35

:

Guess

ing by

using

a

simil

ar

sound

ing

L2

Blue Eyes Intelligence Engineering

\& Sciences Publication 


$\begin{array}{ll}\text { RS11: } & \text { RS36 } \\ \text { Questioni } & : \\ \text { ng 1 } & \text { Rerea } \\ \text { (expressin } & \text { ding } \\ \text { g lack of } & \text { the } \\ \text { sufficient } & \text { unkn } \\ \text { informatio } & \text { own } \\ \text { n in the } & \text { word } \\ \text { text being } & \\ \text { read) } & \\ \text { RS12: } & \text { RS37 } \\ \text { Questioni } & : \\ \text { ng 2 } & \text { Focus } \\ \text { (showing } & \text { ing } \\ \text { disagreem } & \text { on } \\ \text { ent) } & \text { certai } \\ & \text { n } \\ & \text { words }\end{array}$

RS13:

Inference

RS14:

Expressin

g an

opinion or

agreement

RS15:

Confirmin

g or

revising

previous

prediction

\section{RESULTS AND FINDINGS}

The following is a list of reading strategies used by the students and reading problems that they encounter when reading an English text. In order to give a clearer picture of each strategy used, the researcher will provide each strategy with its definition, a sentence of the original text being used in the think aloud (if necessary), and examples extracted from participants' protocols which to indicate strategy use. Comments were also given if needed. As such, the asterisk symbol * will be used to indicate comment on the particular reading strategy.

Participants in the study are allowed to use their mother tongue while thinking aloud to encourage articulation of thoughts. Therefore, their protocols were translated into English. Each translated word will have the square brackets symbols [ ]. However, if the participants used translation as part of the strategy, their protocols will be maintained in their mother tongue and a full translation of the protocols will be made. As such, all of the protocols are in italic and underlined. Angle brackets $<>$ were used to indicate participants' actions.

\section{A. Types of strategies used by Alice}

Alice thought aloud in both English and Malay this is evidenced by the use of both English and Malay language interchangeably while thinking-aloud. She reported using ten strategy types in the think-aloud process and some of the strategies were repeated throughout the think-aloud process. She approached the text in an active way and it was observed that she used text-related strategy (higher-level processing) such as questioning, summarizing, expressing opinion or agreement, and keeping the meaning in mind to comprehend the text better. She also used rereading strategy to help in fostering her comprehension.

Below is the example of Alice's protocols. In her protocols, it was found that Alice frequently used RS20: Questioning 3. There are three types of questioning strategies which Mushait (19) differentiates them into three different categories: questioning 1 (showing lack of sufficient information in the text being read), questioning 2 (showing disagreement), and questioning 3 (showing lack of comprehension). Whenever a reader questions the text by means of showing lack of comprehension, this should indicate that the reader is using RS20: Questioning 3 strategy. According to Mushait (2003), the reader can questioning text either in the form of text or a statement. However, if the answer to the reader's question could be found in the text, it shows lack of understanding, not expressing lack of sufficient information in the text being used (19).

\begin{tabular}{|c|c|c|}
\hline $\begin{array}{c}\text { Readi } \\
\text { ng } \\
\text { strate } \\
\text { gies }\end{array}$ & Original texts & Student's protocols \\
\hline $\begin{array}{l}\text { RS20: } \\
\text { Questi } \\
\text { oning } \\
3 \\
\text { (Show } \\
\text { ing } \\
\text { lack of } \\
\text { compr } \\
\text { ehensi } \\
\text { on) }\end{array}$ & $\begin{array}{l}\text { At every level, our } \\
\text { global narrative is } \\
\text { increasingly } \\
\text { colored by } \\
\text { self-interest. More } \\
\text { and more states } \\
\text { are seeking to } \\
\text { withdraw from } \\
\text { international } \\
\text { agreements, for } \\
\text { example. }\end{array}$ & $\begin{array}{l}\text { 'This is the example for the, } \\
\text { global narrative is increasingly } \\
\text { colored by self-interest.. is it? } \\
\text { Yang ini [this one], More and } \\
\text { more states are seeking...' }\end{array}$ \\
\hline
\end{tabular}




\begin{tabular}{|c|c|}
\hline $\begin{array}{l}\text { One recent } \\
\text { example is the } \\
\text { Government of } \\
\text { India's Aadhaar } \\
\text { online identity }\end{array}$ & $\begin{array}{l}\text { 'I don't really understand this } \\
\text { sentence either. Teething } \\
\text { problems?' }\end{array}$ \\
\hline $\begin{array}{l}\text { verification } \\
\text { system, which, } \\
\text { despite some early } \\
\text { teething troubles, } \\
\text { today rivals } \\
\text { Facebook in its } \\
\text { usage by Indians. }\end{array}$ & \\
\hline $\begin{array}{l}\text { Scaled to include } \\
\text { over one billion } \\
\text { people, Aadhaar } \\
\text { allows } \\
\text { governments, } \\
\text { businesses, } \\
\text { startups and } \\
\text { developers to use a } \\
\text { brand new digital } \\
\text { infrastructure to } \\
\text { solve some of the } \\
\text { country's hardest } \\
\text { problems through } \\
\text { paperless, cashless } \\
\text { and even } \\
\text { presence-less } \\
\text { service delivery. }\end{array}$ & $\begin{array}{l}\text { 'After reading, I'm a bit } \\
\text { confused. And perhaps } \\
\text { Aadhaar is like an online } \\
\text { shopping app because of this } \\
\text { phrase <point at the paper> } \\
\text { 'paperless, cashless and } \\
\text { presence-less service } \\
\text { delivery'.' Now I think maybe } \\
\text { Aadhaar is an online shop? Is } \\
\text { it? }\end{array}$ \\
\hline
\end{tabular}

Alice was also reported using summarizing strategy in her protocols. Summarizing strategy can be defined as a reader summarizes ideas of a sentence, paragraph, or a whole text using his or her own words. This can be done either in English or reader's mother tongue (19). As in this case, Alice was using the Malay language to summarize what she read. Below are some of the examples of her protocols which indicate the used of summarizing strategy by Alice.

\begin{tabular}{|c|c|c|}
\hline $\begin{array}{l}\text { Reading } \\
\text { strategies }\end{array}$ & Original texts & $\begin{array}{l}\text { Student's } \\
\text { protocols }\end{array}$ \\
\hline $\begin{array}{c}\text { RS10: } \\
\text { Summarizing }\end{array}$ & $\begin{array}{l}\text { Businesses are } \\
\text { investing in new } \\
\text { technology to move } \\
\text { forward and drive } \\
\text { growth, but are not } \\
\text { always as enthusiastic } \\
\text { when it comes to } \\
\text { bringing their people } \\
\text { along for the ride. }\end{array}$ & $\begin{array}{l}\text { 'I think that this } \\
\text { err, this paragraph } \\
\text { eh, this sentence is } \\
\text { referring to what } \\
\text { the owners of the } \\
\text { business are doing. } \\
\text { Err, sebagai contoh } \\
\text { [for example] like } \\
\text { they want to do } \\
\text { business erm, but } \\
\text { they do not want }\end{array}$ \\
\hline
\end{tabular}

people to err, a competition in the business because I think they want the business for themselves.'

But it's not for the technology to

So, saya fikir erm, determine that the paragraph ini lebih kepada apa yang destiny it will shape. It teknologi boleh buat is, after all, nothing more than a tool that we have created. As such, we can choose the future our tool can craft for us. It's up to us to make the choices now that will let technology unify, equalize and empower us all in the days to come. untuk kita tetapi kita tidak boleh terlalu bergantung kepada teknologi seperti internet sebab kita masih boleh, how to say? Err, kita boleh bentuk masa depan kita.' [I think this paragraph is more to what the technology can do for us but we can't be too dependable on technology such as internet, because we still can, how to say? We can shape our own future. $]$

Harnessing the power of digital technology to unify, equalize and

'What I know is that untuk belajar empower people on a global scale is no easy tasks. But then, problems worth solving rarely are and yet they must be tackled. If we all play our part, we will all benefit from living in a truly global village.

mengenai teknologi ini bukan mudah-lah tetapi masalah ini harus ditangani. Kalau kita, err, boleh bekerjasama untuk mengatasi masalah ini, kita akan mendapat manfaat juga.' [What I know is that to learn about technology is not simple but this problem needs to be tackled. If we can cooperate in handling this problem, we will gain benefits from it.l 
A good reader always read for meaning and monitoring comprehension. A good reader alert to reading difficulties and plan a strategy to solve the problems (20). Alice planned and monitored her comprehension while reading. There are times her comprehension was interrupted by unknown words or terms. She explicitly identified the unknown words, for example, 'hitherto' and 'debilitating' However, she did not focus on word meaning (lower-level processing) most of the time as she used skipping strategy and continued her reading until she was able to get the gist. This indicates she does not bother with the problem. She appeared to be able to process the meaning of what is read without the need to translate the unknown words into L1 at the word level. Her next strategy was skipping strategy. The skipping strategy is used by the reader when he/she identifies the unknown word/phrases or sentence but decide to skip or ignore it and not returning to it (19). Below is some of Alice's protocols which to indicate skipping strategy.

\begin{tabular}{|c|c|c|}
\hline $\begin{array}{l}\text { Reading } \\
\text { strategies }\end{array}$ & Original texts & Student's protocols \\
\hline $\begin{array}{c}\text { RS28: } \\
\text { Skipping }\end{array}$ & $\begin{array}{l}\text { Like the Sub-Saharan } \\
\text { farmers who are now } \\
\text { able to manage risks and } \\
\text { significantly increase } \\
\text { their yield because they } \\
\text { can access reliable and } \\
\text { timely weather } \\
\text { forecasts, for example, } \\
\text { or Latin America's } \\
\text { hitherto unbanked } \\
\text { population that can now } \\
\text { prove their } \\
\text { creditworthiness using } \\
\text { data gathered from their } \\
\text { use of telecom services. } \\
\text { Digital has become the } \\
\text { language of our world. } \\
\text { In the future, not } \\
\text { knowing the language of } \\
\text { the future will be as } \\
\text { debilitating as illiteracy. }\end{array}$ & $\begin{array}{l} \\
\text { 'I don't understand } \\
\text { 'debilitating'. } \\
\text { DE-BI-litating.' } \\
\text { * In this example, } \\
\text { Alice identified the } \\
\text { problematic word but } \\
\text { she ignored it and } \\
\text { continued reading. }\end{array}$ \\
\hline
\end{tabular}

Another reading strategy used by Alice is keeping the meaning in mind (connect comprehension across text). The use of such strategy often defines reader's ability to connect the new information with the previous one. For example:

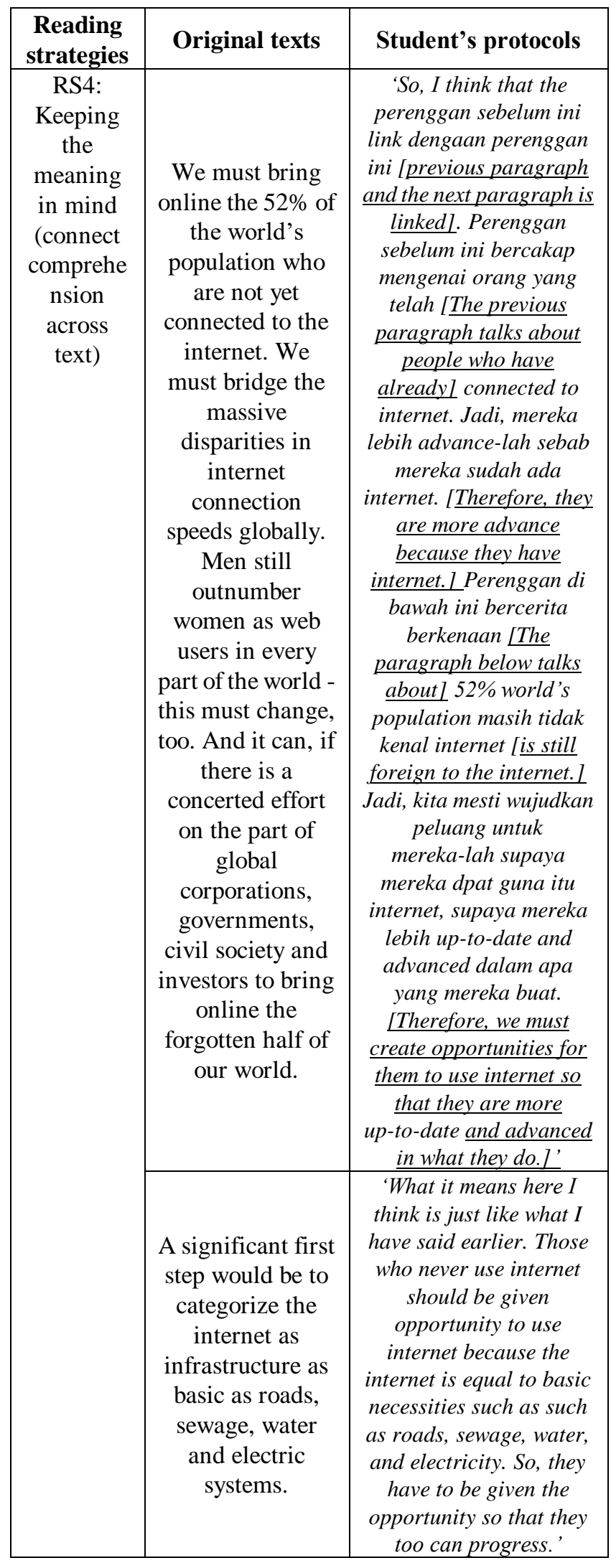

Apart from using cognitive reading strategies, Alice was found using metacognitive reading strategies as well. It can be seen in the protocols given below, she used RS40 (monitoring or evaluating successful comprehension) and RS41 (commenting on strategy used) which indicate that Alice did employ metacognitive reading strategies while reading. Based on her protocols 
below, Alice was aware of her comprehension problem and she monitored her comprehension.

The big hurdle 'Oh, I think that the now is scaling up sentence is like err, these success not complete. It's stories. $\quad$ like Ineed to read further to get general idea.'

A significant first 'Setelah saya baca step would be to lagi sekali baru-lah categorize the saya faham kerana internet as phrasa ini [But after infrastructure as I read back then I basic as roads, understand because sewage, water and there is a phrasel

RS41: electric systems. categorize the

Commenting on strategy used

roads, sewage, water

Reading
strategies

\begin{tabular}{|c|c|c|}
\hline $\begin{array}{l}\text { Reading } \\
\text { strategies }\end{array}$ & Original texts & $\begin{array}{l}\text { Student's } \\
\text { protocols }\end{array}$ \\
\hline \multirow[t]{2}{*}{$\begin{array}{c}\text { RS31: } \\
\text { Referring to } \\
\text { dictionary }\end{array}$} & $\begin{array}{l}\text {...he predicted a world } \\
\text { so unified by an } \\
\text { electronic nervous } \\
\text { system that the human } \\
\text { experience of living } \\
\text { anywhere in the world } \\
\text { would be one of deep } \\
\text { connectedness and } \\
\text { social cohesion - much } \\
\text { like life in small } \\
\text { villages. }\end{array}$ & $\begin{array}{l}\text { 'If social } \\
\text { cohesion, err, let } \\
\text { me check in the } \\
\text { dictionary.' }\end{array}$ \\
\hline & $\begin{array}{l}\text { This gradual erosion of } \\
\text { our shared obligation to } \\
\text { progress more equitably } \\
\text { is creating a deeply } \\
\text { divided world. }\end{array}$ & $\begin{array}{l}\text { 'But I still don't } \\
\text { understand the } \\
\text { word 'erosion'. } \\
<\text { She referred to } \\
\text { dictionary> } \\
\text { Should I read the } \\
\text { meaning to you?' }\end{array}$ \\
\hline
\end{tabular}

She demonstrated her good dictionary skill when there were two suggested meaning found in the dictionary. She was able to relate the correct definition to the context. For instance,

'Alright. From this dictionary, erosion is the process by which the surface of rock or land is gradually damaged by water, wind, etc. or I think, <look back at the second meaning in the dictionary> the gradual reduction or destruction of something important. Ah! This is more related!'

Other frequent strategies used by Alice were rereading and guessing using immediate context. Rereading strategy is often use by the reader to read back a small or large portion of text more than once to facilitate comprehension (19). Meanwhile, guessing using immediate context is a strategy that readers use to guess the meaning of the unknown word. This strategy requires local clues to guess meaning of the unknown word. and electric'. Haha!

The internet should be as important as these basic necessities'. Itu maksud dia [ That is the meaning].

Using a reference such as a dictionary is not a frequent strategy that Alice employed throughout the think-aloud session. As mentioned earlier, she did not focus on word meaning processing as unknown words was not interrupting her overall understanding. She appeared to be able to process the meaning of what was read without the need to translate the unknown words into L1 at the word level. The only time that she was observed of using external source e.g. dictionary was when she thought that the particular unknown words e.g. 'erosion' and 'social cohesion' were important for her understanding.

\begin{tabular}{|c|c|c|}
\hline $\begin{array}{l}\text { Reading } \\
\text { strategies }\end{array}$ & Original texts & Student's protocols \\
\hline & & $\begin{array}{l}\text { 'Yeah, I read back this } \\
\text { part right here.' } \\
\text { 'I'm reading back'. }\end{array}$ \\
\hline $\begin{array}{l}\text { RS 18: } \\
\text { Rereading }\end{array}$ & & $\begin{array}{l}* \text { This strategy was } \\
\text { repeatedly used } \\
\text { throughout the } \\
\text { think-aloud process. }\end{array}$ \\
\hline
\end{tabular}




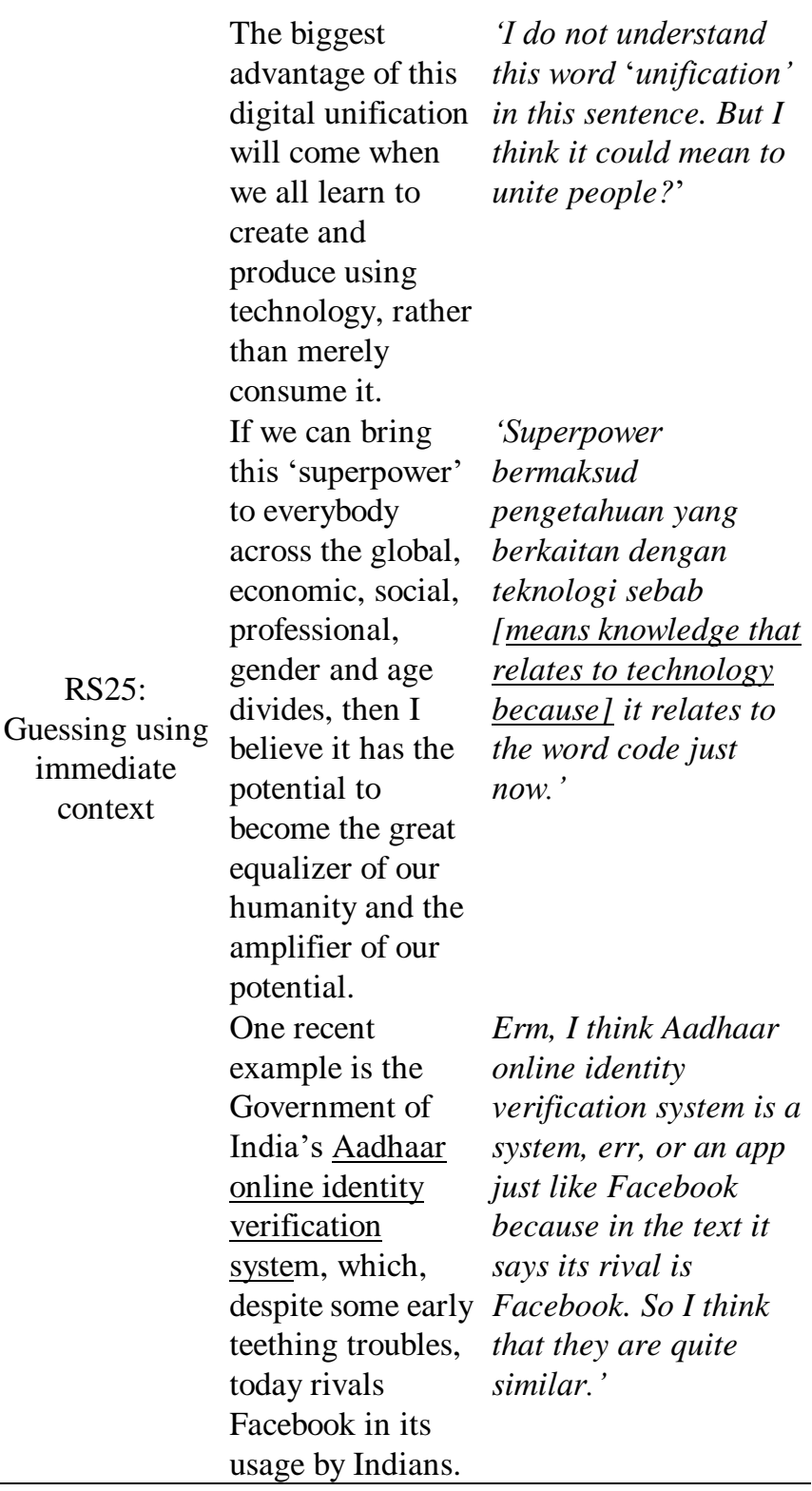

Last but not least, it was reported that Alice did use a strategy called expressing an opinion or agreement. This strategy focuses on a reader expresses his or her opinion to elaborate what has been read, i.e. the content. The intention is to show agreement with the idea presented by the writer. As shown in her protocol below, the author did not mention arguments involved in the last paragraph nor did the author mention in the previous paragraph. However, Alice gives a deep thought about it and relates it with the term 'social cohesion'. This indicates her opinion expression.

\begin{tabular}{|c|c|c|}
\hline $\begin{array}{l}\text { Reading } \\
\text { strategies }\end{array}$ & Original texts & $\begin{array}{c}\text { Student's } \\
\text { protocols }\end{array}$ \\
\hline $\begin{array}{l}\text { RS14: } \\
\text { Expressing } \\
\text { an opinion } \\
\quad \text { or } \\
\text { agreement }\end{array}$ & $\begin{array}{l}\text {...he predicted a world so } \\
\text { unified by an electronic } \\
\text { nervous system that the } \\
\text { human experience of living } \\
\text { anywhere in the world } \\
\text { would be one of deep } \\
\text { connectedness and social } \\
\text { cohesion - much like life in } \\
\text { small villages. }\end{array}$ & $\begin{array}{l}\text { So social } \\
\text { cohesion ini } \\
\text { mungkin } \\
\text { bermaksud [could } \\
\text { mean] all of us } \\
\text { secara [by] social } \\
\text { cohesion <looked } \\
\text { at the dictionary } \\
\text { to reread the } \\
\text { meaning> err, }\end{array}$ \\
\hline
\end{tabular}

\begin{tabular}{l}
\hline mungkin \\
maksudnya semua \\
individu [may be \\
it means that \\
individuals] are \\
united and in \\
good \\
relationships, no \\
arguments. I think \\
so.' \\
\\
Prompt: may I \\
know how do you \\
know that there \\
are no arguments? \\
Does it stated in \\
the text? \\
'No. but I \\
suddenly thought \\
about it and \\
relate it to the \\
text.' \\
\hline
\end{tabular}

\section{B. Reading problems faced by Alice}

Alice's comprehension began to falter when she was no longer able to maintain her attention during text processing. She was experiencing attention-allocation deficits as mentioned by Kendeou, Broek, Helder \& Karlsson (21) in which it was due to detail distraction especially when reading longer texts. Therefore, she failed to focus on the main ideas. Some of the evidence about her attention-allocation deficits are reflected on the part where she could not guess what Aadhaar is although clue is presented in the text; she pointed out that the concept of global village introduced by McLuhan is there will be no arguments and human can live in the North Pole by changing the setting. These indicate in less coherent mental representations of text and this could also indicate that she does not monitor or evaluate her comprehension.

\begin{tabular}{|c|c|}
\hline Original texts & Student's protocols \\
\hline $\begin{array}{l}\text { One recent example is the } \\
\text { Government of India's Aadhaar } \\
\text { online identity verification } \\
\text { system, which, despite some } \\
\text { early teething troubles, today } \\
\text { rivals Facebook in its usage by } \\
\text { Indians. Scaled to include over } \\
\text { one billion people, Aadhaar } \\
\text { allows governments, } \\
\text { businesses, startups and } \\
\text { developers to use a brand new } \\
\text { digital infrastructure to solve } \\
\text { some of the country's hardest } \\
\text { problems through paperless, } \\
\text { cashless, and even }\end{array}$ & $\begin{array}{l}\text { 'After reading, I'm a bit } \\
\text { confused. And perhaps } \\
\text { Aadhaar is like an online } \\
\text { shopping app because of this } \\
\text { phrase <point at the paper> } \\
\text { 'paperless, cashless and } \\
\text { presence-less service } \\
\text { delivery'.' Now I think maybe } \\
\text { Aadhaar is an online shop? Is } \\
\text { it? }\end{array}$ \\
\hline
\end{tabular}


...he predicted a world so unified by an electronic nervous system that the human experience of living anywhere in the world would be one of deep connectedness and social cohesion - much like life in small villages.
'So social cohesion ini mungkin bermaksud all of us secara social cohesion $<$ looked at the dictionary to reread the meaning> err, mungkin maksudnya semua individu are united and in good relationships, no arguments. I think so.'

Prompt: may I know how do you know that there are no arguments? Does it stated in the text?

'No. but I suddenly thought about it and relate it to the text.'

Despite all this, the researcher could not claim that Alice is a strategic reader. It is because a strategic reading requires reading beyond the printed text, to manipulates background knowledge and schemata in order to extrapolate for deeper comprehension (19) in which she did not display it during

\section{Types of strategies used by Hanis}

Hanis spoke aloud mostly in L1. From the protocols, it was found that Hanis used eight types of strategies in which he frequently used translating strategy as a way to facilitate his understanding. Hanis can be categorized as a shallow reader. According to McNamara (1), shallow readers believe that their comprehension are adequate if they can recognize content words and can understand most of sentences. Throughout the think-aloud process, Hanis settled for shallow level of analysis to aid comprehension which is relying so much on translating strategy while trying to comprehend English text. Below are some of the examples of his protocols which indicate translating English in L1.

\begin{tabular}{ccc}
\hline Reading & Original texts & Student's protocols \\
strategies &
\end{tabular}

\begin{tabular}{|c|c|c|}
\hline & $\begin{array}{l}\text { At every level, our } \\
\text { global narrative is } \\
\text { increasingly } \\
\text { colored by } \\
\text { self-interest. }\end{array}$ & $\begin{array}{l}\text { 'Setiap paras } \\
\text { narrative,..' ' 'Every } \\
\text { level narrative,..' }\end{array}$ \\
\hline RS19: & $\begin{array}{l}\text { More and more } \\
\text { states are seeking }\end{array}$ & $\begin{array}{l}\text { 'Maksudnya di sini } \\
\text { lebih banyak }\end{array}$ \\
\hline \multirow[t]{5}{*}{ Translating } & $\begin{array}{l}\text { to withdraw from } \\
\text { international } \\
\text { agreements, for } \\
\text { example. }\end{array}$ & $\begin{array}{l}\text { negara-negara yang } \\
\text { mencari untuk keluar } \\
\text { daripada persetujuan } \\
\text { international sebagai } \\
\text { contoh.' LIt means } \\
\text { that more countries }\end{array}$ \\
\hline & & are seeking to \\
\hline & & withdraw from \\
\hline & & international \\
\hline & & agreement, for \\
\hline
\end{tabular}
think-aloud.

Businesses are
investing in new
technology to
move forward and
drive growth, but
are not always as
enthusiastic when
it comes to
bringing their
people along for
the ride.

This gradual erosion of our shared obligation to progress more equitably is creating a deeply divided world. example]

'Bisnes membuat pelaburan ke atas teknologi baru dan mereka ini ingin bergerak ke hadapan tetapi saya rasa drive growth ini seperti perkembangan rasanya ia bermaksud mempertingkatkan perkembangan tetapi tidak se-enthusiastic kalau perkara yang membuat kita rasa semangat. Tetapi di ayat ini mereka ini tidak berasa semangat atau tidak berminat untuk membawa orang lain.' [Business is investing on the new technology and they want to move forward but I think drive growth is like development. I think it means to further reinforce development but not enthusiastic means things that make us feel enthusiastic but in this sentence it says they are not feeling enthusiastic to bring other people for the ride.l

'Erm, gradual erosion erm, because erosion ini adalah hakisan.

Gradual erosion adalah hakisan yang sekata? Hakisan yang sekata dalam membina sesuatu?' [Erm, gradual erosion erm, because erosion is the process of eroding. Gradual erosion means uniform erosion? A uniform erosion of building something. 1

Furthermore, Hanis also reported using questioning 3 reading strategy (showing lack of comprehension) in his protocols. Below are some of his protocols to indicate such strategy. 


\begin{tabular}{|c|c|c|}
\hline $\begin{array}{c}\text { Reading } \\
\text { strategies }\end{array}$ & Original texts & Student's protocols \\
\hline \multirow{3}{*}{$\begin{array}{l}\text { RS20: } \\
\text { Questioning } 3 \\
\text { (showing lack } \\
\text { of } \\
\text { comprehension } \\
\text { ) }\end{array}$} & $\begin{array}{l}\text { And as } \\
\text { individuals, we } \\
\text { often chase our } \\
\text { dreams without } \\
\text { giving enough } \\
\text { thought to } \\
\text { building more } \\
\text { sustainable and } \\
\text { inclusive } \\
\text { economies and } \\
\text { societies as we do } \\
\text { so. }\end{array}$ & $\begin{array}{l}\text { 'Adakah ia bermaksud } \\
\text { untuk membina lebih } \\
\text { banyak ekonomi dan } \\
\text { society? Erm, saya tidak } \\
\text { fahamlah maksud } \\
\text { sustainable and } \\
\text { inclusive ini.' [Does it } \\
\text { mean to create more } \\
\text { economy and society? } \\
\underline{\text { Erm, I don't understand }} \\
\text { the meaning of } \\
\text { 'sustainable and } \\
\text { inclusive.] }\end{array}$ \\
\hline & $\begin{array}{l}\text { After all, the role } \\
\text { of technology in } \\
\text { increasing } \\
\text { general } \\
\text { inequality has } \\
\text { been the subject } \\
\text { of heated } \\
\text { discussions in } \\
\text { recent times. }\end{array}$ & $\begin{array}{l}\text { 'I think general } \\
\text { inequalities berkaitan } \\
\text { dengan yang di atas ini.' } \\
\text { [links with the one on } \\
\underline{\text { top (previous }} \\
\text { paragraph)] Tapi saya } \\
\text { tidak tahu macam mana. } \\
\text { [Is just that I don't know } \\
\text { how]. }\end{array}$ \\
\hline & $\begin{array}{l}\text { The biggest } \\
\text { advantage of this } \\
\text { digital } \\
\text { unification will } \\
\text { come when we } \\
\text { all learn to create } \\
\text { and produce } \\
\text { using } \\
\text { technology, } \\
\text { rather than } \\
\text { merely consume } \\
\text { it. I }\end{array}$ & $\begin{array}{l}\text { 'I do understand the } \\
\text { writer cakap pasal } \\
\text { manfaat terbesar digital } \\
\text { unification tetapi err, } \\
\text { saya tidak faham } \\
\text { maksud unification } \\
\text { [talks about the greatest } \\
\text { benefit in digital } \\
\underline{\text { unification but I don't }} \\
\underline{\text { understand the meaning }} \\
\text { of unification]. }\end{array}$ \\
\hline
\end{tabular}

Other common reading strategies used by $\mathrm{L} 2$ readers to comprehend English text are keeping in mind (connect comprehension across text), rereading, guessing using immediate context, and referring to dictionary. These strategies were employed by Hanis when reading an English text and some has been used repeatedly while thinking aloud.

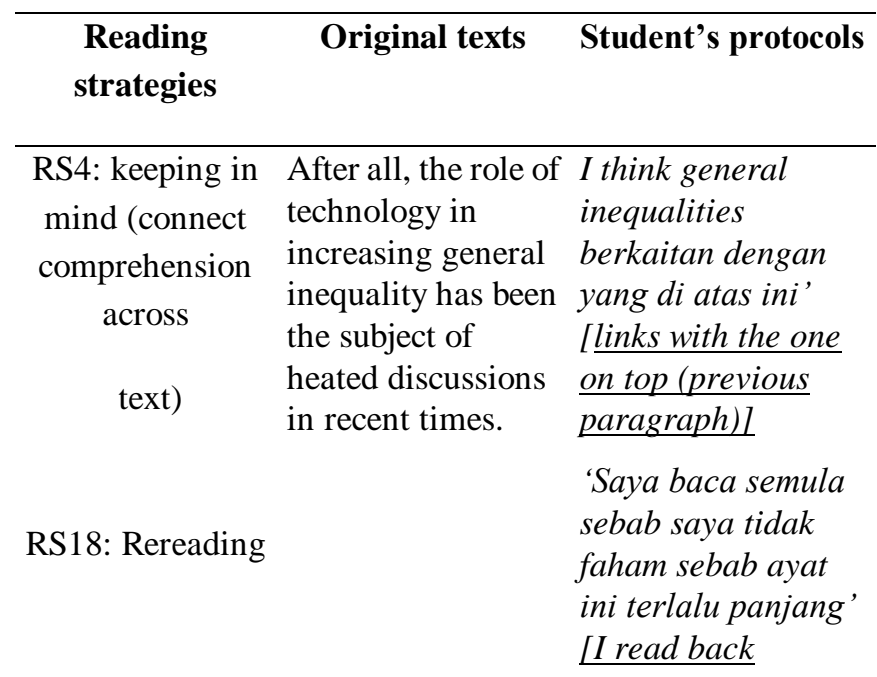

because I don't understand because the sentence is too longl.

'Err, kejap, saya baca balik' [Wait, I read back].

'Wait a minute; let me read again the next sentence.'

Like the

Sub-Saharan farmers who are now able to manage risks and significantly increase their yield because they can

RS25: Guessing access reliable and using immediate timely weather context forecasts, for example, or Latin America's hitherto unbanked population that can now prove their creditworthiness using data gathered from their use of telecom services.
'Saya tidak tahu maksud hitherto ini. Mungkin dia bermaksud puak etnik di latin America.' [ $\underline{\text { I don't }}$ understand what hitherto is. Perhaps it is an ethnic group of Latin America]. 
The biggest advantage of this digital unification will come when we all learn to create and produce using technology, rather than merely consume it.
I do understand the writer cakap pasal manfaat terbesar digital unification tetapi err, saya tidak faham maksud unification [talks about the greatest benefit in digital unification but I don't understand the meaning of unification]. Mungkin saya patut mencari maksudnya di dalam kamus' LPerhaps I should refer to dictionary.]

* Although her inferencing is wrong, he attempted to guess the meaning of an unknown word. This indicates a strategy used by the reader.

Hanis was also reported to use personal experience in relating with what he read. Below are some of protocols which reflect on Hanis strategy employment.

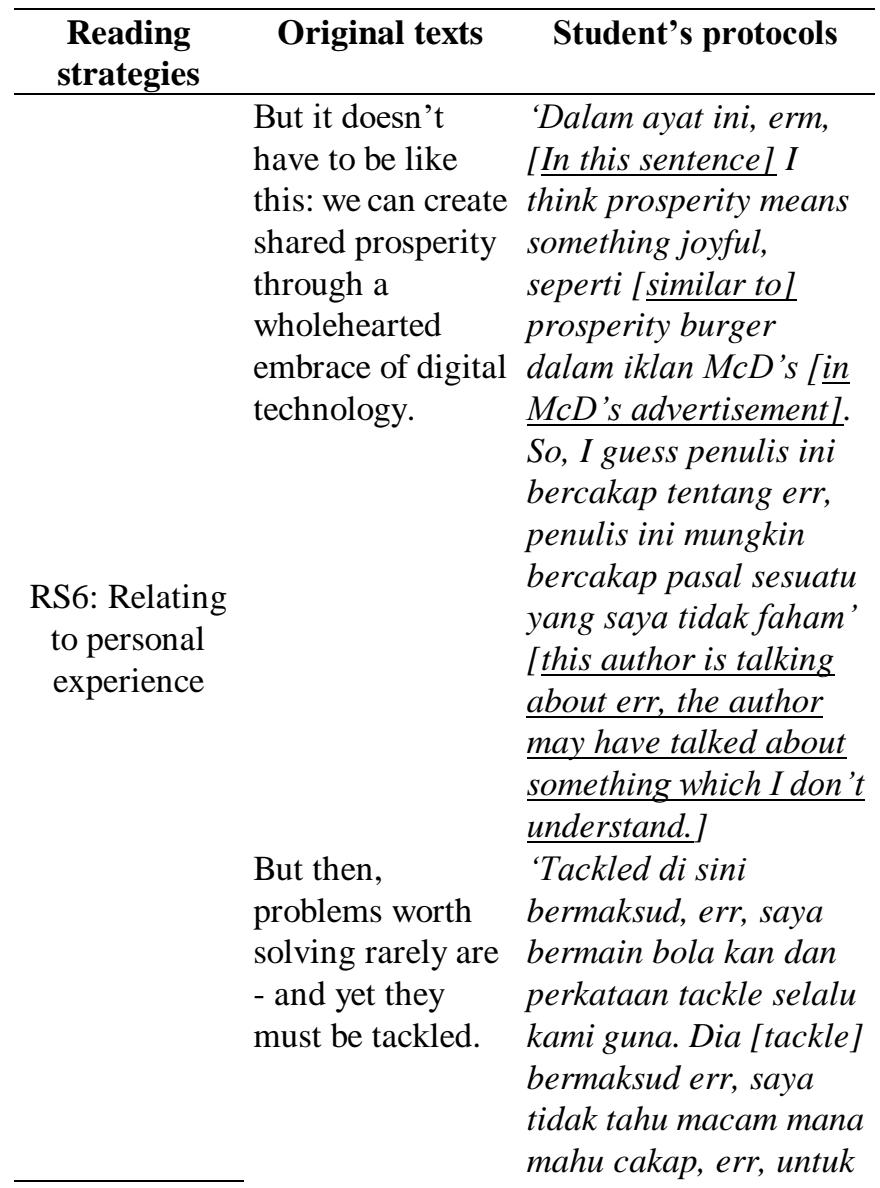

membuang, seperti membuang object yang berada di depan kamu. So, di dalam ayat ini, dia bercakap berkenaan masalah yang harus dibuang.' Tackled here means, err, I play football and tackle often one of the word we used to say in the football term. It means err, I don't know how to say, err, to remove, it's like to remove the object in front of you. So, in this sentence, it says that problems must be removed.'

Digitization can deliver that 'Digitization reminds me of one of telecom much-needed service which is Digi.' sense of oneness for our fractured world. It's up to us to embrace it. ...he predicted a world so unified by an electronic nervous system that the human experience of living anywhere in the world would be one of deep connectedness and social cohesion - much like life in small villages.

'Electronic nervous
system adalah seperti
badan manusia macam
tu, ada sistem' [is like a
human body, there is a
$\underline{\text { system]. So, the }}$
electronic nervous
system ada kaitan
dengan komputer [ $\underline{\text { has }}$
to do with the
computer].

Last but not least, Hanis was reported guessing the meaning of an unknown word using morphology / grammar. Below is the protocol which indicates of such strategy being used by Hanis. In his protocols, Hanis was making use of word root to guess the meaning of an unknown word. At the beginning, Hanis tried to refer the meaning of the word unification in the dictionary. However, the word is not listed in the dictionary. Therefore, Hanis guessed the meaning of the word using morphology / grammar strategy. 


\begin{tabular}{|c|c|c|}
\hline $\begin{array}{c}\text { Reading } \\
\text { strategies }\end{array}$ & Original texts & Student's protocols \\
\hline $\begin{array}{l}\text { RS34: Guessing } \\
\text { by using } \\
\text { morphology / } \\
\text { grammar }\end{array}$ & $\begin{array}{l}\text { The biggest } \\
\text { advantage of this } \\
\text { digital unification } \\
\text { will come when we } \\
\text { all learn to create } \\
\text { and produce using } \\
\text { technology, rather } \\
\text { than merely } \\
\text { consume it. }\end{array}$ & $\begin{array}{l}\text { 'Saya rasa } \\
\text { unification ini } \\
\text { datang daripada } \\
\text { perkataan unify' [I } \\
\text { think unification } \\
\text { comes from the word } \\
\underline{\text { unify]. }}\end{array}$ \\
\hline
\end{tabular}

\section{Reading problems faced by Hanis}

Based on the data, it was reported that Hanis' greatest obstacle in comprehending an English text is due to unfamiliar words. He reported to have difficulties in understanding words such as sustainable, inclusive, unification, and hitherto. Since translation is his most popular strategy choice, his direct translation strategy did not aid him to have a better understanding. For instance, he translated gradual erosion as uniform erosion, which leads him to be more confused. Other than this, Hanis self-reported to have a problem in reading longer sentence where he has to reread in order to understand the text better.

\section{E. What do they have in common?}

Firstly, the role of vocabulary in assisting reading comprehension in both L1 and L2 is important (22). Based on their think-aloud protocols, the participants reported to encounter unknown word as their comprehension obstacle. Due to this reason the participants were not able to construct a visual representation of a word if the meaning is unknown. This indicates that vocabulary is the key factor affecting their comprehension which needs to be addressed.

Secondly, the researcher could not claim that they were demonstrating a high metacognitive awareness in reading an English text although both participants were able to understand the reading text to a certain degree. This is because they reported to use eighteen strategies which mostly are text-related and word-related strategies. Occasionally, Alice was reported using metacognitive strategies but it was not enough to claim that she is a good reader as some of her comprehensions were misleading. On the other hand, Hanis did not reflect what good readers do. Hanis does not seem to have a purpose in reading. He lacked of the metacognitive strategies to facilitate deeper levels of comprehension such as inferences, linking ideas coherently, scrutinizing the validity of claim with a critical stance, and recognizing author's motives. Most of the think-aloud data showed that Hanis concentrated more on translating sentences into L1. He did not report of reading the title of the text nor did he skimming the text before engage in reading. Other than that, Hanis did not thinking about his progress in learning as he was eager to complete the task without reflecting on it. However, to say that Hanis do not employ metacognitive strategies at all in his reading would seem to be unfair. Although Hanis did not report using metacognitive strategies in the think-aloud, it might have been used automatically without him consciously aware.

\section{CONCLUSION}

To conclude, a strategic reader or skilled reader will always demonstrate the following actions: 1) planning what strategy to use while reading, 2) monitoring his/her strategy choice, and 3) monitoring or evaluating her comprehension. Based on the findings, it shows that the participants are having limited strategies repertoires to help them in understanding the text better. A possible reason for the lacking of metacognitive strategies in reading is that students do not have adequate metacognitive awareness. In response to this concern, teaching metacognitive reading strategies should be taken into account in developing students' reading comprehension. In other word, language teachers should teach their students metacognitive strategies explicitly as part of their reading instruction so that their comprehension skills can be developed.

\section{ACKNOWLEDGEMENT}

We would like to express our thanks to Marcus Kho for his assistance in collecting the data for this study.

\section{REFERENCES}

[1] McNamara DS (Ed.). Reading comprehension strategies: Theories, interventions, and technologies. Psychology Press.; 2012.

[2] Woolley G. Reading Comprehension: Assisting children with learning difficulties. In: Springer Science \& Business Media. 2011. p. 15-34.

[3] Eskey DE. Reading in a second language. In: In Hinkel, E (Ed) Handbook of research in second language teaching and learning. NJ: Erlbaum: Mahwah; 2005. p. 563-79.

[4] Boulware-Gooden, R., Carreker, S., Thornhill, A. and Joshi RM. Instruction of Metacognitive Strategies Enhances Reading Comprehension and Vocabulary Achievement of Third-Grade Students. Read Teach. 2007;61:70-7.

[5] Meniado JC. Metacognitive reading strategies, motivation, and reading comprehension performance of saudi EFL students. English Lang Teach. 2016;9(3):117-29.

[6] Anderson NJ. Teaching Reading. In D. Nunan (Ed.). In: Practical English Language Teaching. New York: McGraw Hill Publishers; 2003.

[7] Brown, A. L. and Palincsar AS. Inducing strategic learning from texts by means of informed, self-control training. 1982.

[8] Brown AL. Learning, Remembering, and Understanding. Technical Report No. 244. 1982.

[9] Flavell JH. Metacognitive aspects of problem solving. in L. B. Resnick (Ed.). In: The nature of intelligence. Hillsdale, NJ: Erlbaum; 1976. p. 231-5.

[10] Flavell JH. Metacognition and cognitive monitoring: A new area of cognitive-developmental inquiry. Am Psychol. 1979;34(10):906-11.

[11] Schraw G. Promoting general metacognitive awareness. Instr Sci. 1998;26(1):113-25.

[12] Wenden AL. Metacognitive knowledge and language learning. Appl Linguist. 1998;19(4):515-37.

[13] Livingston JA. Metacognition: An overview. 2003;

[14] Schraw, G. \& Moshman D. Metacognitive theories. Educ Psychol Rev. 1995;7(4):351-71.

[15] Efklides A. The role of metacognitive experiences in the learning process. Psicothema. 2009;21(1)

[16] Anderson NJ. Metacognition and good language learners. In: In C Griffiths (Ed), Lessons from good language learneres. Cambridge: Cambridge University Press; 2008. p. 99-109.

[17] O'Malley, J. M. and Chamot AU. Learning strategies in second language acquisition. Cambridge university press.; 1990.

[18] Parekh SS. The internet can end global inequality. Here's how. [Internet]. World Economic Forum. 2018 [cited 2018 Jan 30]. Available from: https://www.weforum.org/agenda/2018/01/the-internet-end-global-ineq uality/

[19] Mushait SA. The relationship of L1 reading and L2 language proficiency with the L2 reading comprehension and strategies of Saudi EFL university students. (Doctoral dissertation, University of Essex); 2003 
[20] Block EL. See how they read: Comprehension monitoring of L1 and L2 readers. TESOL Q. 1992;26(2):319-43.

[21] Kendeou, P., Broek, P. V. D., Helder, A., and Karlson J. A cognitive view of reading comprehension: Implications for reading difficulties. Learn Disabil Res Pract. 2014;29(1):10-6.

[22] Lawrence, J. Z. and Suani A. The Role of Vocabulary in Reading Comprehension: The Case of Secondary School Students Learning English in Singapore. RELC J. 2008;39(1):51-76.

\section{Author Profile}

I am Mornita Deri, currently I am affiliated with Universiti Teknologi Malaysia, 81310 Johor Bahru, Malaysia, mornita.d@ gmail.com

I am Sarimah Shamsudin, currently I am affiliated with Language Academy, Universiti Teknologi Malaysia, 54000 Kuala Lumpur, Malaysia. 